\title{
ЗНАЧЕННЯ ПЕРФУЗІЙНОГО ІНДЕКСУ ДЛЯ ШВИДКОЇ ДІАГНОСТИКИ РІЗНИХ ФОРМ СИНДРОМУ ДІАБЕТИЧНОӦ СТОПИ В ВИБОРІ АДЕКВАТНОӦ ПАТОГЕНЕТИЧНОЇ ТАКТИКИ ХІРУРГІЧНОГО ЛІКУВАННЯ
}

\author{
○ Ю. М. Футуйма, А. Д. Беденюк, І. Я. Кульбаба \\ Тернопільський національний медичний університет імені І. Я. Горбачевського МОЗ України
}

РЕЗЮМЕ. В статті представлено особливості стану об'ємного периферійного капілярного кровотоку при нейропатичній, нейроішемічній та ішемічній формах синдрому діабетичної стопи, що визначається методом фотоплетизмографії під час виконання пульсоксиметрії та можливості їх використання для швидкої діагностики вказаних форм разом із загальноприйнятними методиками.

Мета - вивчити особливості показників перфузійного індексу фотоплетизмографічним методом за допомогою пульсоксиметра на периферії нижніх кінцівок у хворих із різними формами синдрому діабетичної стопи з метою подальшого їх діагностичного застосування в медичній практиці.

Матеріал і методи. Проаналізовано результати дослідження 89 осіб, в тому числі 15 осіб, які склали контрольну групу, й 74 пацієнти, які мали різні форми СДС з гнійно-некротичними ускладненнями з боку нижніх кінцівок, що відповідають III-V ступеням ураження за Meggit-Wagner. Невропатичну форму діагностовано у 38 (51,4 \%), невроішемічну - у 30 (40,5 \%), ішемічну -у 6 (8,1 \%) пацієнтів. Оцінку статусу артеріальної крові на нижніх кінцівках визначали за допомогою пульсоксиметрії неінвазивним фотоплезматичним методом за допомогою приладу RocSea.

Результати. Методика дослідження, апробована нами в даній роботі, дозволяє застосування поширеного останнім часом та легкодоступного методу визначення показників ПІ для швидкої диференційної діагностики хворих із різними формами ускладненого синдрому діабетичної стопи при цукровому діабеті 2-го типу та в подальшому впровадження його в практичну діяльність, що дасть можливість вибрати той чи інший патогенетичний підхід до вибору тактики подальшого хірургічного та медикаментного лікування.

Висновки. Пульсоксиметрія є простим, доступним та найдешевшим методом швидкої діагностики порушень периферійного кровообігу при різних формах СДС, які непрямим способом відображають стан периферійного кровообігу в ділянці стопи та можуть бути використані для швидкої об'єктивності подальшого вибору тактики лікування кожного пацієнта зокрема, а також як метод моніторингу ефективності патогенетичного підходу до хірургічної та медикаментної корекції ускладнень синдрому діабетичної стопи на етапах лікування.

КлючОВІ словА: перфузійний індекс; фотоплетизмографія; синдром діабетичної стопи; пульсоксиметрія.

Вступ. Підхід до лікування ускладнених форм цукрового діабету, а саме синдрому діабетичної стопи (СДС), вимагає суворого алгоритму дій, що включають детальне клінічне обстеження, дані рівня глікемії та додаткових лабораторних показників, інструментальних методів обстеження (ультрасонографія судин, рентгенобстеження стопи) $[6,11]$. Одними з найінформативніших та, разом з тим, і найдороговартісніших обстежень $\epsilon$ рентгеноконтрастна ангіографія, МРТ з контрастуванням, радіонуклідна ангіографія [7, 10]. «Золотим стандартом» на сьогодні $€$ ультразвукове дослідження артерій нижніх кінцівок у режимі візуалізації направленого кольорового кровотоку з можливістю застосування ефекту Доплера та визначенням кісточково-плечового індексу, що $\epsilon$ цінними прогностичними маркерами при виборі подальшої тактики хірургічного лікування ускладнень даної патології $[2,8]$. Тому дослідження в царині швидкої, доступної, недорогої діагностики $\epsilon$ першочерговими, особливо в екстрених ситуаціях, коли правильно вибраний патогенетичний підхід до хірургічного лікування дає можливість швидко зупинити негативний вплив етіологічно- го фактора, що спричинив захворювання, а нерідко й врятувати кінцівку чи життя пацієнта [1].

Метод пульсоксиметрії, що ґрунтується на основі фотоплетизмографії, застосовується анестезіологами для безперервного гемодинамічного моніторингу у пацієнтів як з критичними станами, так і під час виконання операційних утручань, та $\epsilon$ достатньо простим, доступним та інформативним, відображає стан гемодинамічних порушень цілого організму [4]. Оскільки цей метод дає інформацію про стан периферійного кровотоку, виникла думка про можливість його застосування для діагностики нейропатичної, нейроішемічної чи ішемічної форм СДС на основі змін перфузійного індексу. Індекс перфузії, або перфузійний індекс (ПІ), $є$ показником стану об'ємного периферійного кровотоку, що визначається методом фотоплетизмографії під час проведення пульсоксиметрії. Механізм реєстрації ПІ за даним методом характеризується процесом реєстрації зміни об'єму внаслідок звуження чи розширення просвіту судин під дією артеріальної пульсації, що викликає зміну амплітуди сигналу та отримується на виході з фотодетектора $[3,9]$. 
Огляди літератури, оригінальні дослідження, погляд на проблему, випадок з практики, короткі повідомлення

Величина перфузійного індексу коливається в діапазоні 0,02 - $20 \%$. Слід враховувати, що достовірність вказаного показника залежить від таких факторів як інтенсивність об'ємного периферійного кровообігу; заповнення судинного русла кров'ю; від кількості працюючих капілярів $[5,12]$. Саме порушення вказаних факторів і спостерігають при нейроішемічній формі СДС.

Мета роботи - вивчити особливості показників перфузійного індексу фотоплетизмографічним методом за допомогою пульсоксиметра на периферії нижніх кінцівок у хворих із різними формами синдрому діабетичної стопи з метою подальшого їх діагностичного застосування в медичній практиці.

Матеріал і методи дослідження. Дослідження виконувалось в клініці хірургії № 1 імені проф. л. Я. Ковальчука на базі Тернопільської університетської лікарні в період 2020-2021 років. У дослідження включені 89 осіб, з них 74 з різними формами СДС та 15 - контрольна група. Контрольну групу склали особи чоловічої та жіночої статей віком від 29 до 74 років з числа студентів, колег по роботі, родичів та пацієнтів, які добровільно погодилися ввійти в дану групу обстежуваних, без ознак неврологічних судинних уражень нижніх кінцівок, що підтверджено дослідженнями неврологічного статусу, УЗД нижніх кінцівок, визначення КПІ, що застосовуються в діагностиці СДС. Пацієнти з СДС, в яких виявлені гнійно-некротичні ускладнення з боку нижніх кінцівок, що відповідають III-V ступеням ураження за Meggit-Wagner, поділені на 3 групи: 1-ша - з невропатичною формою (38 хворих $(51,4 \%)$ ); 2-га - з невроішемічною (30 $(40,5$ \%)); 3-тя - з ішемічною - (6 (8,1 \%)). Розподіл за формами здійснювали на основі обстеження неврологічного статусу, УЗД судин нижніх кінцівок, рентгенологічного обстеження стопи та визначення КП у всіх без винятку пацієнтів. 3 даних груп виключені пацієнти, в яких були явні ознаки гангрени усіх пальців чи дистального відділу кукси, що автоматично унеможливлює проведення дослідження через відсутність кровообігу по капілярній сітці. 1-й групі відповідали пацієнти з III ступенем ураження з гострими чи хронічними гнійними ураженнями пальців чи дистального відділу стопи, але за умов збереження кровообігу, 2-ій - з III-IV ступенями, з наявною сухою гангреною одного чи кількох пальців при збереженні кровообігу в інших, а також у поєднанні з гнійними ураженнями, 3-й - 3 IV-V ступенями з критичною ішемією, при якій КП <0,39. Неінвазивну оцінку статусу артеріальної крові на нижніх кінцівках визначали за допомогою пульсоксиметрії фотоплезматичним методом за допомогою приладу RocSea, який дозволяє одночасно визначати 4 показники: \% $\mathrm{SpO}_{2}$ - насичення артеріальної крові киснем (сатурацію); bpmPR частоту пульсу; PI\% - індекс перфузії, RR - частоту дихання. Окрім того, для об'єктивної оцінки стану пацієнта визначали дані пульсоксиметрії і на пальцях рук. Оцінюючи зміни васкуляризації, при яких, як наслідок, відбуваються зміни теплопродукції, визначали температуру на нижніх кінцівках за допомогою безконтактного інфрачервоного термометра Неасо DT-8806S. Цей пристрій дозволяє вимірювати температуру на поверхні тіла з точністю до $0,1^{\circ} \mathrm{C}$ та в діапазоні температури тіла від $30,0^{\circ} \mathrm{C}$ до $43{ }^{\circ} \mathrm{C}$. Дослідження виконували в 3 точках: по внутрішньому краю середньої третини стегна в проекції стегнової артерії; по задньому краю литкового м'яза в проекції його переходу в ахіловий сухожилок; на тильній поверхні стопи в 1 міжпальцевому просторі. Вказані вироби відповідають вимогам Технічного регламенту щодо медичних виробів, затвердженого постановою Кабінету міністрів України від 02.10.2013 № 753, мають знаки відповідності вимогам та сертифікати відповідності.

Результати й обговорення. Умовами для виконання даного дослідження $\epsilon$ відсутність пошкодження нігтьових пластинок, відсутність ознак дефекту шкіри на пальці, фіксація кінцівки в горизонтальному положенні тіла, запобігання попаданню яскравого світла на датчик, відсутність на пальці мазей, жирових виділень, достатній рівень гемоглобіну в крові (не нижче 80 г/л), оскільки при низькому показнику зменшується доставка в тканини кисню, достатня температура на поверхні пальця.

У значної кількості хворих виявлено грибкове ураження нігтів. Перед дослідженням тим пацієнтам, в яких воно було виявлено, проводили медичний педикюр за допомогою фрезера (мікромоту) Marathon 3 Champion українсько-корейської фірми SaeYang Ukraine, що використовується в медичній подології, досягаючи товщини нігтьової пластинки не менше 0,5 мм, потім обробляли пальці спиртом, зігрівали кінцівку, вимірювали температуру на поверхні обстежуваної ділянки, тільки після цього виконувалось дослідження (рис. 1).

Обстеження, виконані в контрольній групі на вказівному пальці рук, вказують, що показник сатурації (кількість кисню, зв'язаного з Нb в системі кровообігу) - \% $\mathrm{SpO}_{2}$ становить $(97,93 \pm 0,38)$, перфузійний індекс - PI\% - $(5,01 \pm 0,47)$. При невропатичній формі вони статистично не відрізняються від контрольних величин та становлять, відповідно $(97,0 \pm 0,66)$ та $(4,26 \pm 0,65)$. При невроішемічній формі показник \% $\mathrm{SpO}_{2}$ пальцях рук дорівнює $(96,67 \pm$ $0,43)$ а PI\% - $(3,45 \pm 0,35)$, що на $31,1 \%$ нижче від показника здорових людей $(P<0,05)$. При ішемічній формі даного захворювання відмічається знижен- 
Огляди літератури, оригінальні дослідження, погляд на проблему, випадок з практики, короткі повідомлення
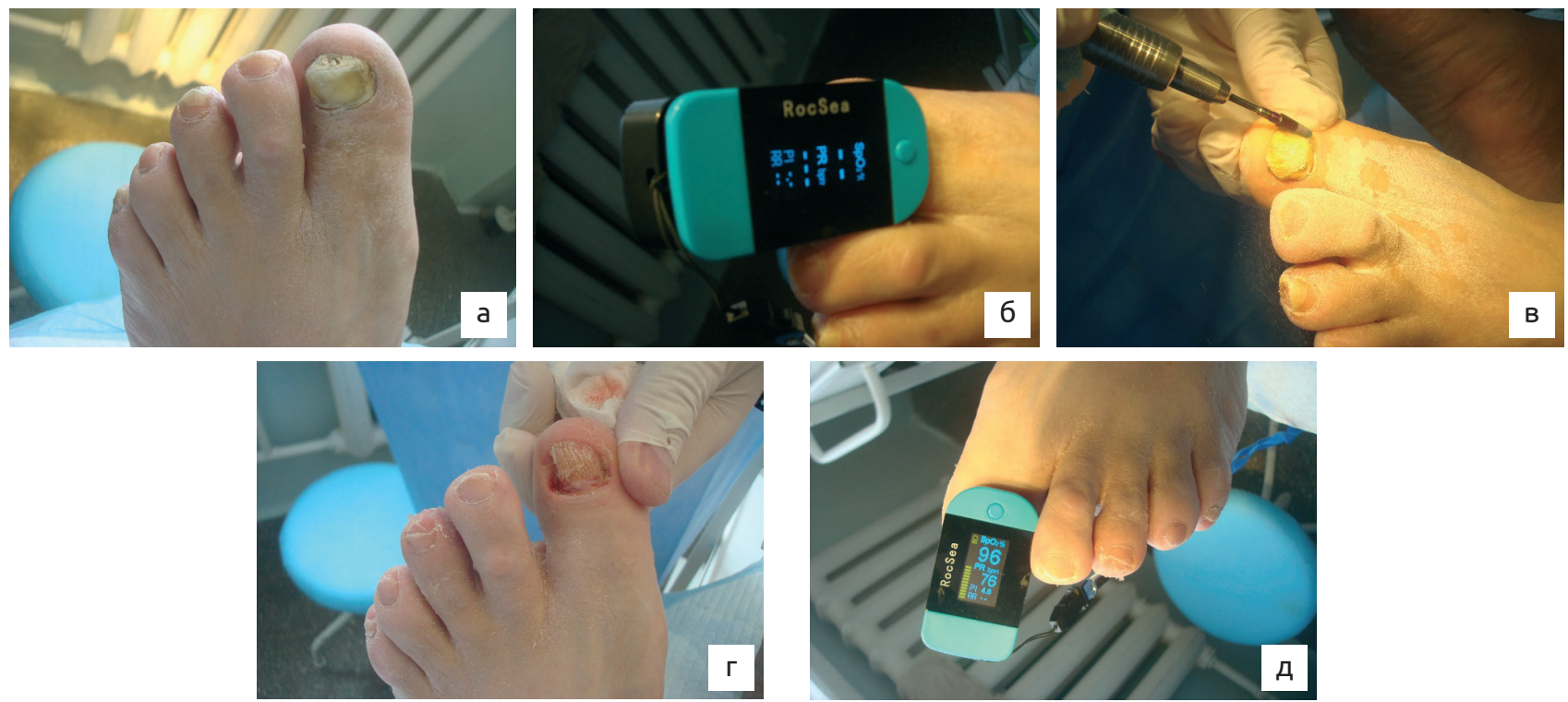

Рис. 1. Приклад виконання пульсоксиметрії у хворого з цукровим діабетом 2-го типу та оніхомікозом нігтьової пластинки 1-го пальця під час амбулаторного огляду: а - оніхомікоз 1 пальця лівої стопи; 6 - показники на пристрої не визначаються; в - медичний педикюр; г- вигляд нігтя після корекції; д- показники на пристрої визначаються.

ня перфузії та насиченості киснем з високим ступенем достовірності $(P<0,01)$ не тільки на периферії нижніх кінцівок, а й на периферії рук, та становить,

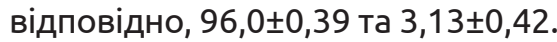

В той же час на нижній кінцівці \% $\mathrm{SpO}_{2}$ у здорових осіб складає $(97,67 \pm 0,31), \mathrm{PI} \%-(2,25 \pm 0,33)$, що на 44,9\% ( $\mathrm{P}<0,001)$ нижче, порівняно з даними на кисті, що ми пов'язуємо із природним зменшенням сили пульсу в місці виміру в зв'язку з удвічі більшою відстанню периферичних судин на стопі від серця, порівняно з такими на кисті. КПІ

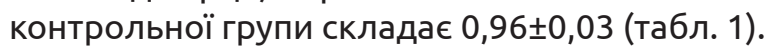

Таблиця 1. Показники оксигенації артеріальної крові та локальної температури (ㄷ) на периферії нижніх кінцівок у контрольній групі та у хворих з різними формами синдрому діабетичної стопи

\begin{tabular}{|l|c|c|c|c|}
\hline \multicolumn{1}{|c|}{ Показник } & $\begin{array}{c}\text { Контрольна група } \\
(n=15)\end{array}$ & $\begin{array}{c}\text { Невропатична форма } \\
\text { СДС }(n=38)\end{array}$ & $\begin{array}{c}\text { Невроішемічна форма } \\
\text { СДС }(n=30)\end{array}$ & $\begin{array}{c}\text { Ішемічна форма СДС } \\
(n=6)\end{array}$ \\
\hline$\% \mathrm{SpO}_{2}$ & $97,67 \pm 0,31$ & $97,00 \pm 0,68$ & $78,6 \pm 8,94^{*}$ & - \\
\hline $\mathrm{PI \%}$ & $2,25 \pm 0,33$ & $2,78 \pm 0,61$ & $0,57 \pm 0,28^{* * *}$ & - \\
\hline $\mathrm{K}$ II & $0,96 \pm 0,03$ & $0,91 \pm 0,03$ & $0,44 \pm 0,04^{* * *}$ & $0,28 \pm 0,02^{* * *}$ \\
\hline$t^{\circ}-$ стегно & $36,18 \pm 0,09$ & $36,89 \pm 0,19^{* *}$ & $35,74 \pm 0,13^{* *}$ & $35,17 \pm 0,06^{* * *}$ \\
\hline$t^{\circ}-$ гомілка & $35,86 \pm 0,11$ & $36,85 \pm 0,34^{* *}$ & $35,25 \pm 0,21^{*}$ & $34,52 \pm 0,13^{* * *}$ \\
\hline$t^{\circ}-$ стопа & $35,61 \pm 0,13$ & $37,15 \pm 0,37^{* * *}$ & $34,80 \pm 0,24^{* *}$ & $32,77 \pm 0,15^{* * *}$ \\
\hline
\end{tabular}

Примітка. Зірочкою позначені величини, що статистично достовірно відрізняються від контрольних (* - Р<0,05; ** - Р<0,01; $* * *-P<0,001)$.

У пацієнтів 1-ї групи (див. табл. 1) рівень $\mathrm{SpO}_{2}$ на периферії пальців ніг при госпіталізації стано-

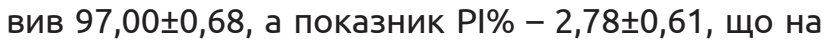
$19,1 \%$ ( $P>0,05)$ вище показника норми та у першому і другому випадках достовірно не відрізняється від даних здорових осіб (P>0,05). КПІ в цій групі ста-

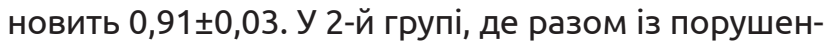
нями неврологічного характеру на перше місце виступають ураження судин у вигляді медіокальцинозучи атеросклеротичнихураженьпериферичних судин нижніх кінцівок, що характеризується їхнім звуженням і, відповідно, сповільненням кровообігу та кисневим дефіцитом, - показник $\mathrm{SpO}_{2}$ складає, в середньому, 78,6ะ8,94, з достовірною різницею в порівнянні з показниками як контрольної, так і 1-ї груп (Р<0,05). Відповідно, середні дані PI\% дорівнювали 0,57士0,28, що на 74,7 \% менше показника контрольної (P<0,001) та на 79,5 \% мен-

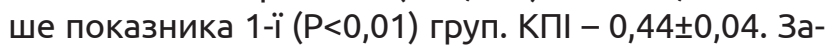
уважимо, що в 3-х осіб з даної групи ми не могли визначити вказані показники, та змогли їх визначити на 3-7 добу після хірургічного та медикаментного лікування, і лише до 14 доби показники сягнули мінімального рівня, який можна визначити за допомогою пульсоксиметра. В 3-й групі КПІ скла-

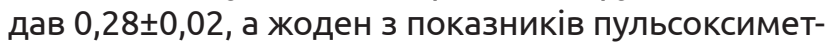
рії не визначався, що пов'язано з повною відсутністю ефективного кровообігу при цій формі СДС. 
Огляди літератури, оригінальні дослідження, погляд на проблему, випадок з практики, короткі повідомлення

Вивчення особливостей теплопродукції на периферії вказує, що у хворих у першу добу госпіталізації при нейропатичній формі, яка супроводжується гнійними ураженнями кістково-суглобового апарату стопи з розвитком флегмон, температура на периферії збільшена за рахунок запалення, яке сприяє активному кровообігу, що й підтверджує показник пульсового індексу. При локальному вимірі на стопі в 1 міжпальцевому проміжку середня температура складає $(37,15 \pm$ $0,37)^{\circ} \mathrm{C}$, порівняно з середнім показником в даній точці у пацієнтів контрольної групи - $(35,61 \pm$ $0,13){ }^{\circ} \mathrm{C}$ i, не зважаючи на їі незначний відсоток в різниці температур між вказаними показниками (до 4,32 \%), різниця достовірності між ними за t Стьюдента складає $(\mathrm{P}<0,001)$. Від периферії до центру показник температури незначно знижується, порівняно з даними на стопі, однак з достовірною різницею $(\mathrm{P}<0,01)$ від такого ж в контрольній групі, та становить $(36,85 \pm 0,34){ }^{\circ} \mathrm{C}$ проти $(35,86 \pm 0,11){ }^{\circ} \mathrm{C}$ - на гомілці та $(36,89 \pm 0,19){ }^{\circ} \mathrm{C}$ проти $(36,18 \pm 0,09)^{\circ} \mathrm{C}-$ на стегні. При невроішемічній формі, де гнійні ускладнення рідко супроводжують ураження стопи, а негативні зміни здійснюються за рахунок судинного компонента, різниця температур характеризується наступним чином: на стегні в ділянці виміру вона в середньому складає $(35,74 \pm 0,13)^{\circ} \mathrm{C}$ та $\epsilon$ меншою на $1,2 \%$, порівняно $з$ контролем, з різницею достовірності $(P<0,01)$. На гомілці різниця температур складає $(35,25 \pm$ $0,21)^{\circ} \mathrm{C}, \epsilon$ на $1,7 \%$ меншою від середнього показника контролю з достовірністю $(P<0,05)$. Визначено значно нижчий показник в цій групі на стопі, що становить $(34,80 \pm 0,24)^{\circ} \mathrm{C}$ з різницею достовірності $(\mathrm{P}<0,01)$ щодо нормального значення. Якщо ж порівняти дані температур на стопі при невропатичній та невроішемічній формах, то їх різниця складе 6,33 \% з достовірністю $(P<0,001)$ між показниками. При ішемічній формі, де діагностується значне ураження судин на периферії, температура має ще більшу тенденцію до зниження на периферії і складає на стегні - $(35,17 \pm 0,06)^{\circ} \mathrm{C}$, гомілці - $(34,52 \pm 0,13){ }^{\circ} \mathrm{C}$, стопі - $(32,77 \pm 0,15)^{\circ} \mathrm{C}$ й свідчить не тільки про значні порушення теплообміну, а й про знижений критичний рівень кровообігу, що в подальшому призводить до розвитку гангрен стопи та гомілки. Таким пацієнтам виконано ампутації на рівні середньої третини гомілки при умовах збереженого кровообігу чи ампутацію на рівні нижньої третини стегна при повній оклюзії підколінно-гомілкового сегментів судин, що підтверджено іншими інструментальними методами діагностики (УЗД, КТ, МРТ).

Висновки. 1. Сучасний метод фотоплетизмографії за допомогою пульсоксиметрії $\epsilon$ простим, доступним та найдешевшим методом швидкої діагностики порушень периферійного кровообігу при різних формах СДС.

2. Показники сатурації та перфузійного індексу непрямим способом відображають стан периферійного кровообігу в ділянці стопи та можуть бути використані для швидкої об'єктивності в подальшому виборі тактики лікування кожного пацієнта зокрема.

3. Значення рівня температур на поверхні різних ділянок нижньої кінцівки теж можуть бути використані в якості діагностичних маркерів та вказують на зміни теплопродукції й, разом з тим, кровотоку, в той чи інший бік при різних формах даного захворювання.

4. Визначення вказаних показників в процесі лікування може бути застосовано як метод моніторингу ефективності патогенетичного підходу до хірургічної, медикаментної чи поєднаної корекцій ускладнень синдрому діабетичної стопи.

Перспективи подальших досліджень. Вивчення кореляційного зв'язку об'ємного стану периферійного кровообігу нижніх кінцівок за методом пульсоксиметрії з морфометричними, морфологічними особливостями судин стопи, показниками напруженості кисню $\left(\mathrm{TspO}_{2}\right)$ методом транскутанної оксиметрії у хворих з гнійно-некротичними ускладненими при різних формамах СДС.

\section{ЛІТЕРАТУРА}

1. Економічні та медико-соціальні проблеми в лікуванні синдрому діабетичної стопи / П. О. Герасимчук, О. В. Шідловський, Д. Б. Фіра, Р. Я. Кушнір, А. В. Махніцький // Матеріали Всеукраїнської науково-практичної конференції з міжнародною участю «Сучасний мультидисциплінарний підхід до діагностики та лікування хворих на цукровий діабет», Тернопіль. 11-12 травня 2017. - Тернопіль, 1917. - С. 20-21.

2. Заремба В. С. До питання діагностики та лікування синдрому діабетичної стопи у хворих на цукровий діабет 2 типу / В. С. Заремба, Н. Р. Федишин // Клі-

нічна анатомія та оперативна хірургія. - 2017. - Т. 16, № 3. - С. 47-49.

3. Курсов С. В. Перфузионный индекс в практике анестезиологии и интенсивной терапии (Обзор литературы) / С. В. Курсов // Медицина неотложных состояний. - 2015. - № 7 (70). - С. 20-25.

4. Курсов С. В. Екстрена оцінка об'ємного периферійного кровообігу та стану волемії за результатами фотоплетизмографічного дослідження / С. В. Курсов, К. І. Лизогуб // Здобутки клінічної і експериментальної медицини. - 2015. - № 1. - С. 149-150. 
Огляди літератури, оригінальні дослідження, погляд на проблему, випадок з практики, короткі повідомлення

5. Пульсоксиметрія та безпека пацієнта під час хірургічних втручань / Ю. Л. Кучин, К. Ю. Бєлка, О. М. Іноземцев [та ін.] // Біль, знеболення та інтенсивна терапія. -2017. - № 1. - С. 77-80.

6. Причини виникнення та діагностика синдрому діабетичної стопи / В. І. Ляховський, О. Л. Гавловський, О.О.Кизименко [та ін.] // Вісник ВДНЗУ «Українська медична стоматологічна академія». - 2018. - Т. 18, Випуск 1 (61). - С. 318-322.

7. Покровский А. В. Клиническая ангиология : руководство / А. В. Покровский. - М. : Медицина, 2004. Т. 2. $-888 \mathrm{C}$.

8. Brownrigg J. R. W. Effectivenes of bedside investigalions to diagnose peripheral artery disease amond people with diabetes mellitus: a systematic review / J. R. W. Brownrigg, R. J. Hinchliffe, J. Apelqvist // Diabetes Metab. Res. Rev. - 2016. - Vol. 32 (Sup. 1). - P.119-127

\section{REFERENCES}

1. Herasymchuk, P.O., Shidlovskyi, O.V., Fira, D.B., Kushnir, R.Ya., \& Makhnitskyi, A.V. (2017). Ekonomichni ta medyko-sotsialni problemy $v$ likuvanni syndromu diabetychnoi stopy [Economic and medical and social problems in the treatment of diabetic foot syndrome]. Suchasnyi multydystsyplinarnyi pidkhid do diahnostyky ta likuvannia khvorykh na tsukrovyi diabet : materialy Vseukrainskoi naukovo-praktychnoi konferentsii z mizhnarodnoiu uchastiu [Modern multidisciplinary approach to the diagnosis and treatment of patients with diabetes: materials of the AllUkrainian scientific-practical conference with international participation]. Ternopil [in Ukrainian].

2. Zaremba, V.S., \& Fedyshyn, N.R. (2017). Do pytannia diahnostyky ta likuvannia syndromu diabetychnoi stopy u khvorykh na tsukrovyi diabet 2 typu [Questions to diagnosis and treatment diabetic foot syndrome in patients with type 2 diabetes]. Clinichna anatomia ta operatyvna khirurhia - Clinical Anatomy and Operative Surgery, 16 (3), 47-49. DOI: 10.24061/1727-0847.16.3.2017.79 [in Ukrainian].

3. Kursov, S.V. (2015). Perfuzionnyj indeks v praktike anesteziologii i intensivnoj terapii (Obzor literatury) [Perfusion index in the practice of anesthesiology and intensive care (Literature review)]. Meditsyna neotlozhnykh sostoianiy - Emergency Medicine, 7 (70), 20-25. [in Russian].

4. Kursov, S.V., \& Lyzogub, K.I. (2015). Ekstrenna otsinka obyemnoho peryferiynoho krovoobihu ta stanu volemiyi za rezultatamy fotopletyzmohrafichnoho doslidzhennya [Emergency assessment of volumetric peripheral circulation and volemia according to the results of photoplethysmographic examination]. Zdobutky klinichnoi i eksperymentalnoi medytsyny-Achievements of Clinical and Experimental Medicine, 1, 149-150. DOI: https://doi.org/10.11603/18112471.2015.v22.i1.4249 [in Ukrainian].

5. Kuchyn, Yu.L., Byelka, K.Yu., Inozemcev, O.M., Yurovich, A., Dimov, B., \& Melnyk, I. (2017). Pulsoksymetriya ta bezpeka paciyenta pid chas khirurhichnykh vtruchan [Pulse-
9. Perfusion index. Clinical Applications of perfusion Index / Masimo Corporation URL: http://www.infiniti.se/ upload/servicemanual/masimo/beskrivning_piwhite\%20 paper.pdf \& http://www.masimo.com/pdf/whitepaper/ lab3410f.pdf

10. Diabetic foot disease: impact of ulcer location on ulcer healing / K. M. Pickwell, V. D. Siersma, M. Kars [et al.] // Diabetes Metab. Res. Rev. - 2013. - No. 29 (5). P. 377-383.

11. Pokorma J. Importance of education in the prevention of diabetic foot syndrome. / J. Pokorma // Neuro Endocrinol. Lett. - 2017. - No. 38 (4) . -255-256.

12. Tissue Oxygen Saturation and Finger Perfusion Index in central Hypovolemia: Influence of Pain / L. Hoiseth, J. Hisdal, I.E. Hoff [et al.] // Critical. Care. Medicine. - 2015. Vol. 43, No. 4. - P. 747-756. oximetry and patient safety during surgery]. Bil, znebolennia ta intensyvna terapiya - Pain, Anaesthesia \& Intensive Care, 1 (78), 77-80. [in Ukrainian].

6. Liakhovskyi, V.I., Havlovskyi, O.L., Kyzymenko, O.O., Liulka, O.M., \& Horodova-Andrieieva, T.V. (2018). Prychyny vynyknennia ta diahnostyka syndromu diabetychnoi stopy [Diabetic foot syndrome: its causes and diagnosis]. Visnyk VDNZU "Ukrainska medychna stomatolohichna academia" - Bulletin of VDNZU "Ukrainian Medical Dental Academy», 18 ((1)(61)), 318-322. [in Ukrainian].

7. Pokrovskyi, A.V. (2004). Klynycheskaia anhyolohyia: Rukovodstvo [Clinical Angiology: A Guide] Moscow: Medicine [in Russian].

8. Brownrigg, J.R.W., Hinchliffe, R.J., Apelqvist, J., Boyko, E.J., Fitridge, R., Mills, J. L., Reekers, J., \& Schaper, N.C. (2016). Effectivenes of bedside investigalions to diagnose peripheral artery disease amond people with diabetes mellitus: a systematic review. Diabetes Metab. Res. Rev, 32 (1), 119-127. DOI: 10.1002/dmrr.2703

9. Perfusion index. Clinical Applications of perfusion Index / Masimo Corporation. Retrieved from: http://www. infiniti.se/upload/servicemanual/masimo/beskrivning_piwhite\%20paper.pdf.

10. Pickwell, K.M., Siersma, V.D., Kars, M., Holstein, P.E., \& Schaper, N.C. (2013). Diabetic foot disease: impact of ulcer location on ulcer healing. Diabetes Metab. Res. Rev, 29 (5), 377-383. DOI:10.1002/dmrr.2400

11. Pokorma, J. (2017). Importance of education in the prevention of diabetic foot syndrome. Neuro Endocrinol. Lett, 5 ((38(4)), 255-256.

12. Hoiseth, L., Hisdal, J., Hoff, I.E., Hagen, O.A., Landsverk, S.A., \& Kirkeboen, K.A. (2015). Tissue Oxygen Saturation and Finger Perfusion Index in central Hypovolemia: Influence of Pain. Critical Care Medicine, 43 (4), 747756. DOI: $10.1097 / C C M .0000000000000766$ 

СИНДРОМА ДІАБЕТИЧЕСКОЙ СТОПЫ ПРИ ВЫБОРЕ АДЕКВАТНОЙ ПАТОГЕНЕТИЧЕСКОЙ ТАКТИКИ ХИРУРГИЧЕСКОГО ЛЕЧЕНИЯ

\author{
( Ю. М. Футуйма, А. Д. Беденюк, И. Я. Кульбаба
}

Тернопольский национальный медицинский университет имени И. Я. Горбачевського МОз Украины

РЕЗЮМЕ. В статье представлены особенности состояния объемного периферического капиллярного кровотока при нейропатической, нейроишемической и ишемической формах синдрома диабетической стопы, определяемого методом фотоплетизмографии во время проведения пульсоксиметрии, и возможности их использования для быстрой диагностики указанных форм наряду с общепринятыми методиками.

Цель - изучить особенности показателей перфузионного индекса фотоплетизмографическим методом с помощью пульсоксиметра на периферии нижних конечностей у больных с различными формами синдрома диабетической стопы с целью дальнейшего их диагностического применения в медицинской практике.

Материал и методы. Проанализированы результаты исследования 89 лиц, в том числе 15 лиц, составивших контрольную группу, и 74 пациента, которые имели различные формы СДС с гнойно-некротическими осложнениями со стороны нижних конечностей, соответствующими III-V степеням поражения по Meggit-Wagner. Heвропатическая форма диагностирована у 38 (51,4 \%), невроишемическая - у 30 (40,5\%), ишемическая - у 6 (8,1\%) пациентов. Оценку статуса артериальной крови на нижних конечностях определяли с помощью пульсоксиметрии неинвазивным фотоплезмографическим методом с помощью прибора RocSea.

Результаты. Методика исследования, апробированная нами в данной работе, позволяет применение распространенного в последнее время и легкодоступного метода определения показателей ПИ для быстрой дифференциальной диагностики больных с различными формами осложненного синдрома диабетической стопы при сахарном диабете 2-го типа и в дальнейшем внедрение его в практическую деятельность, что позволит выбрать тот или иной патогенетический подход к выбору тактики дальнейшего хирургического и медикаментозного лечения.

Выводы. Пульсоксиметрия является простым, доступным и дешевым методом быстрой диагностики нарушений периферического кровообращения при различных формах СДС, которые косвенно отражают состояние периферического кровообращения в области стопы и могут быть использованы для быстрой объективизации дальнейшего выбора тактики лечения каждого пациента в частности, а также как метод мониторинга эффективности патогенетического подхода к хирургической и медикаментозной коррекции осложнений синдрома диабетической стопы на этапах лечения.

КЛЮЧЕВЫЕ СЛОВА: перфузионный индекс; фотоплетизмография; синдром диабетической стопы; пульсоксиметрия.

\title{
SIGNIFICANCE OF THE PERFUSION INDEX FOR QUICK DIAGNOSIS OF DIFFERENT FORMS OF DIABETIC FOOT SYNDROME IN THE CHOICE OF ADEQUATE PATHOGENIC TACTICS
}

\section{@Yu. M. Futuyma, A. D. Bedenyuk, I. Ya. Kulbaba \\ I. Horbachevsky Ternopil National Medical University}

SUMMARY. The article presents the features of the volume of peripheral capillary circulation in neuropathic, neuroischemic and ischemic forms of diabetic foot syndrome, which is determined by photoplethysmography during pulse oximetry and the possibility of their use for rapid diagnosis of these forms along with conventional techniques.

The aim - to study the features of perfusion index by photoplethysmographic method using a pulse oximeter on the periphery of the lower extremities in patients with various forms of diabetic foot syndrome in order to further their diagnostic use in medical practice.

Material and Methods. The results of the study in 89 people, of which 15 are the control group and 74 patients with various forms of VTS, in which purulent-necrotic complications of the lower extremities corresponding to III-V degrees of Meggit-Wagner lesions were analyzed. The neuropathic form was diagnosed in 38, which is - (51.4 \%), neuroischemic in $30(40.5 \%)$, ischemic - in $6(8.1 \%)$ of all patients. Assessment of arterial blood status in the lower extremities was determined by pulse oximetry by non-invasive photoplasmic method using a RocSea instrument.

Results. The research method tested by us in this work allows the use of widely used in the recent period and easily accessible method for determining PI for rapid differential diagnosis of patients with various forms of complicated diabetic foot syndrome in type 2 diabetes mellitus and their subsequent application in practice, which will opportunity to choose one or another pathogenetic approach to the choice of tactics for further surgical and medical treatment.

Conclusions. Pulse oximetry is a simple, affordable and cheapest method of rapid diagnosis of peripheral circulatory disorders in various forms of VTS, which indirectly reflects the state of peripheral blood circulation in the foot and can be used for rapid objectivity of further treatment tactics of each patient pathogenetic approach to surgical and medical correction of complications of diabetic foot syndrome at the stages of treatment.

KEY WORDS: perfusion index; photoplethysmography; diabetic foot syndrome; pulse oximetry.

Отримано 22.04.2021 